\title{
Relation between daylight ratio, plasma progesterone levels and timing of nidation in mink (Mustela vison)
}

\author{
Catherine Allais and Lise Martinet
}

\author{
Station centrale de Physiologie animale-I.N.R.A., 78350 Jouy-en-Josas, France
}

\begin{abstract}
Summary. Mink were mated between 17 February and 22 March. In females kept in natural daylight concentrations of progesterone, measured by radioimmunoassay, began to rise between 25 and $30 \mathrm{March}$, whatever the date of mating. After reaching peak values of $40-160 \mathrm{ng} / \mathrm{ml}$, progesterone concentrations decreased before the end of pregnancy. In females given $14 \mathrm{~h}$ light $/ 24 \mathrm{~h}$ immediately after mating, the rise of progesterone began a few days earlier, indicating that the extra light induces earlier progesterone secretion, nidation and parturition.
\end{abstract}

\section{Introduction}

The reproductive cycle of the mink is annual and the breeding season very short, extending from the end of February to the end of March. Female mink exhibit natural delayed blastocyst nidation which leads to a variable gestation period lasting from 40 to 74 days (Hansson, 1947). Usually, the later mating occurs in the breeding season, the shorter is the gestation period and an artificial increase in the light photoperiod after mating reduces the gestation period (Belaiev, Klotchkov \& Zhelezova, 1963; Aulerich, Holcomb, Ringer \& Schaible, 1963). The termination of diapause is associated with the secretion of progesterone by the activated corpora lutea (spotted skunk: Mead \& Eik-Nes, 1969; badger : Bonnin-Laffargue, Canivenc \& Ribes, 1978; mink: Møller, 1973). In the mink, the progesterone concentration begins to rise 7-10 days before implantation (Møller, 1973). Because the mink is the only species having an obligatory form of delayed implantation and exhibiting a variable period of diapause, the present study was undertaken to determine the relation between date of mating, plasma progesterone rise before implantation and daylight ratio.

\section{Materials and Methods}

The 16 mink used were 2-3-year-old ranch females of the pearl colour phase. Females (10) in the control group were kept outside under natural daylight and temperature conditions. The daily photoperiod for these animals increased from $10 \mathrm{~h} 32 \mathrm{~min}$ on 22 February to $14 \mathrm{~h}$ in late April. The experimental animals (6) were also housed outside under natural temperature conditions but a daylight ratio of $14 \mathrm{~h}$ light $/ 24 \mathrm{~h}(14 \mathrm{~L}: 10 \mathrm{D})$ was given by adding extra light from $06: 00$ to $20: 00 \mathrm{~h}$, beginning the day after mating until the end of pregnancy. The extra light from 25-W bulbs gave 129-194 lx to the animals depending upon cage location. All females were mated once with a fertile male between 17 February and 22 March; copulation lasted from 10 to $80 \mathrm{~min}$.

Blood samples were taken 1-3 times a week during the whole gestation period. The animals were lightly anaesthetized with ketamine hydrochloride and the blood was withdrawn into a heparinized syringe by cardiac puncture.

The methods used for extraction and radioimmunoassay have been described previously (Caillol $\&$ Martinet, 1976). The antiserum was raised in rabbits immunized with $11 \alpha$-hemisuccinate progesterone conjugated to bovine serum albumin. This antiserum was highly specific, the only crossreaction obtained being $7 \cdot 5 \%$ with $5 \alpha$-pregnane-3,20-dione. All the samples were measured in duplicate. Recoveries ranged from 70 to $90 \%$. Agreement between known amounts of progesterone added to plasma from castrated mink and the amounts recovered was good (coefficient of correlation $=0.98$; slope $=0.92$ ). The sensitivity of the standard curve was $10-25 \mathrm{pg} / \mathrm{ml}$ and blank values were always less than this. The intra- and inter-assay variations were $14 \%$ and $20 \%$, respectively. 


\section{Results}

Sixteen females were used in this study (Table 1) but only 4 females whelped : 2 from the control group on 3 and 6 May and 2 from the experimental group on 18 and 30 April. Five females did not give birth, presumably because they were pseudopregnant or had lost the litter before parturition. Seven females, of which 6 were pregnant, died during the blood sampling period.

Table 1. Mating, parturition and autopsy dates in control (Nos. 1-10) and experimental (Nos. 11-16) female mink

\begin{tabular}{|c|c|c|c|c|c|}
\hline Female & $\begin{array}{l}\text { Date of } \\
\text { mating }\end{array}$ & $\begin{array}{c}\text { Date of } \\
\text { parturition }\end{array}$ & $\begin{array}{l}\text { No. of } \\
\text { young }\end{array}$ & $\begin{array}{c}\text { Date of } \\
\text { death }\end{array}$ & $\begin{array}{c}\text { State of } \\
\text { pregnancy }\end{array}$ \\
\hline 1 & 17 Feb. & (did not whelp) & $\ldots$ & - & - \\
\hline 2 & $23 \mathrm{Feb}$. & - & - & 13 April & 5 blastocysts \\
\hline 3 & 24 Feb. & (did not whelp) & - & - & - \\
\hline 4 & 2 March & 3 May & 5 & 一 & - \\
\hline 5 & 2 March & (did not whelp) & - & - & 一 \\
\hline 6 & $10 \mathrm{March}$ & 6 May & 1 & - & - \\
\hline 7 & 10 March & (did not whelp) & - & - & - \\
\hline 8 & 12 March & - & - & 18 April & 1 implantation site \\
\hline 9 & 19 March & - & 一 & 13 April & Not pregnant \\
\hline 10 & 22 March & - & - & 22 April & 7 fetuses \\
\hline 11 & 22 Feb. & - & - & 15 April & 5 fe tuses \\
\hline 12 & 22 Feb. & (did not whelp) & - & - & - \\
\hline 13 & 24 Feb. & 18 April & 5 & - & 一 \\
\hline 14 & 7 March & 30 April & 4 & - & - \\
\hline 15 & 7 March & - & - & 24 April & 5 fetuses \\
\hline 16 & $9 \mathrm{March}$ & - & - & $28 \mathrm{March}$ & 7 implantation sites \\
\hline
\end{tabular}

\section{Plasma progesterone concentrations}

Natural daylight. As shown in Text-fig. 1 the progesterone levels remained basal during the first days after coitus $(0-8 \mathrm{ng} / \mathrm{ml})$. This lag period decreased from 31 days for females mated in late February (Text-fig. 1a) to 6 days for females mated in late March (Text-fig. 1d). A rapid increase in the progesterone concentrations began at the same time in 8 females out of the 10 between 25 and 30 March, whatever the date of mating. In Female 4, mated on 2 March (Text-fig. 1b), the progesterone values rose between 30 March and 5 April while in Female 10, mated on 22 March, the increase occurred only between 4 and 9 April.

Peak values varied from 40 to $160 \mathrm{ng} / \mathrm{ml}$, depending on the individual. After the peak value was reached, the progesterone concentrations declined gradually until the day of parturition. The pattern of progesterone evolution in females which failed to whelp was similar to that in normal pregnancy.

Extra light. An artificial increase of the photoperiod to $14 \mathrm{~L}: 10 \mathrm{D}$ for females mated between 17 and 24 February resulted in the plasma progesterone rise being shortened (Text-fig. 1e) in comparison with that of control females mated at the same time (Text-fig. 1a): the increased progesterone levels occurred between 10 and 20 March. Similarly when mating was between 7 and 10 March the plasma progesterone values increased between 20 and 25 March (Text-fig. 1f), a few days before they did in the females from the control group (Text-fig. 1c).

Text-fig. 1. Plasma progesterone levels in female mink (- , pregnant; ---, pseudopregnant or barren) housed in natural conditions of daylight and temperature (Nos 1-10) or given extra light, $14 \mathrm{~h} \mathrm{light} / 24 \mathrm{~h}$ (Nos 11-16). The times of mating were (a) 17-24 February; (b) 2 March; (c) 10-12 March; (d) 19-23 March; (e) 17-24 February; (f) 7-10 March. The hatched area indicates the period when progesterone concentrations began to increase. 

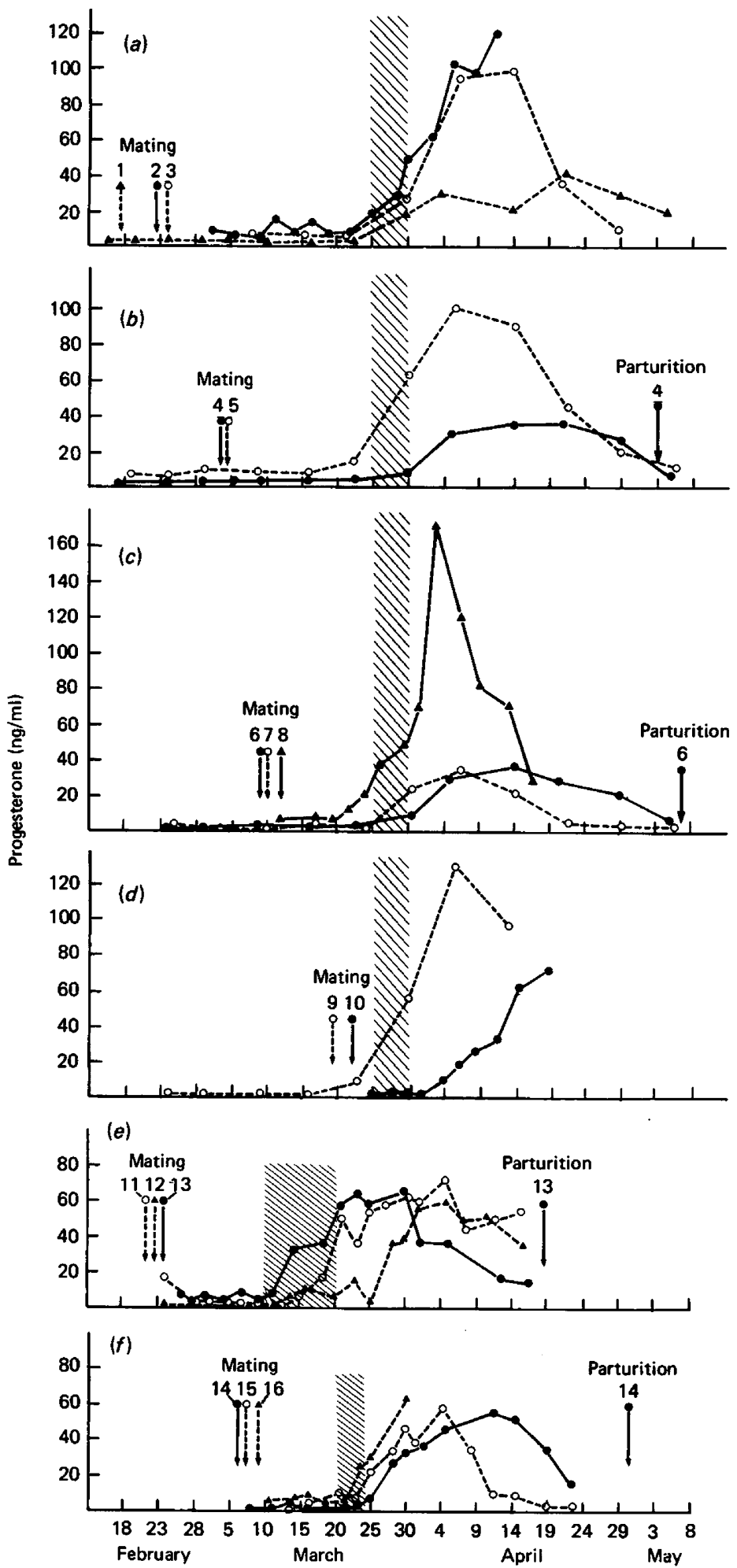


\section{Discussion}

The progesterone levels in mink plasma during pregnancy follow the pattern described by Møller (1973), who used a protein-binding assay, and by Murphy \& Moger (1977) who used a radioimmunoassay. The great variation in the peak values observed in females in the present study could be due to the sampling technique: repeated anaesthesia and heart punctures were very stressful. However, the daily administration of ketamine to the rhesus monkey did not alter blood oestrogen and progesterone levels throughout the menstrual cycle (Channing, Fowler, Engel \& Vitek, 1977).

Under natural daylight conditions, the plasma progesterone levels increased at the same time (25-30 March) for all the females. Since the interval between nidation and parturition in mink is about 30 days (Enders, 1952) and plasma progesterone begins to increase at about 40 days before parturition (Møller, 1973), nidation should take place between 5 and 10 April, whatever the date of mating. Increasing the daily light period induces earlier progesterone secretion and therefore nidation, although treatment with exogenous progesterone does not induce nidation (Hansson, 1947; Cochrane \& Shackelford, 1962).

The mustelid luteotrophic hormone is not known at present, but the identical evolution of plasma progesterone during pregnancy or pseudopregnancy shows that the mink feto-placental unit has little (Møller, 1973) or no (Canivenc, Bonnin-Laffargue \& Lajus, 1966) luteotrophic action. As in the spotted skunk (Mead, 1971), the induction of the preimplantation rise of progesterone by extra light suggests that pituitary factors are involved in the luteotrophic process in mink.

We thank Dr F. Dray and Dr M. Terqui for providing us with the antiprogesterone antibody.

\section{References}

Aulerich, R.J., Holcomb, L., Ringer, R.K. \& Schaible, P.J. (1963) Influence of photoperiod on reproduction in mink. Q. Bull. Mich. St. Univ. agric. Exp. Stn 46, 132-138.

Belaiev, D.K., Klotchkov, D.V. \& Zhelezova, A.J. (1963) The influence of light condition on the reproductive function and fertility in mink (Mustela vison Schr.). Byull. mosk. Obshch. Ispȳt. Prir., Otd. Biol. 78, 107-125. [in Russian.]

Bonnin-Laffargue, M., Canivenc, R. \& Ribes, Cl. (1978) Plasma progesterone in the badger (Meles meles). J. Reprod. Fert. 52, 55-58.

Caillol, M. \& Martinet, L. (1976) Preliminary results on plasma progesterone levels during pregnancy and superfetation in the hare, Lepus europaeus.J. Reprod. Fert. 46, 61-64.

Canivenc, R., Bonnin-Laffargue, M. \& Lajus, $M$. (1966) L'utérus gravide a-t-il une fonction lutéotrope chez le vison (Mustela vison) ? C. r. Séanc. Soc. Biol. 160, 2285-2287.

Channing, C.P., Fowler, S., Engel, B. \& Vitek, K. (1977) Failure of daily injections of ketamine $\mathrm{HCl}$ to adversely alter menstrual cycle length, blood estrogen and progesterone levels in the rhesus monkey. Proc. Soc. exp. Biol. Med. 155, 615-619.

Cochrane, R.L. \& Shackelford, R.M. (1962) Effects of exogenous oestrogen alone and in combination with progesterone on pregnancy in the intact mink. J. Endocr. 25, 101-106.

ENDERS, R.K. (1952). Reproduction in the mink (Mustela vison). Proc. Am. phil. Soc. 96, 691-755.

Hansson, A. (1947) The physiology of reproduction in mink (Mustela vison) with special reference to delayed implantation. Acta zool. Stockh. 28, 1-136.

MEAD, R.A. (1971) Effects of light and blinding upon delayed implantation in the spotted skunk. Biol. Reprod. 5, 214-220.

MeAD, R.A. \& EiK-Nes, K.B. (1969) Seasonal variation in plasma levels of progesterone in western forms of the spotted skunk. J. Reprod. Fert., Suppl. 6, 397-403.

Møller, D.M. (1973) The progesterone concentrations in the peripheral plasma of the mink (Mustela vison) during pregnancy. $J$. Endocr. 56, 121-132.

Murphy, B.D. \& Moger, W.H. (1977) Progestins of mink gestation: the effects of hypophysectomy. Endocr. Res. Commun. 4, 45-60.

Received 4 January 1978 